\title{
Jubilujúca Viera Žemberová
}

\section{Eliška Gunišová (Brno)}

Rok 2018 so sebou prináša významné životné jubileum poprednej osobnosti slovenskej literárnovednej obce, prof. PhDr. Viery Žemberovej, CSc. (*1948), ktorej nespochybnitelný a pretrvávajúci prínos pre vedecké bádanie, poznanie, no i vysokoškolské vzdelávanie môžeme pri tejto príležitosti opätovne ocenit v jeho plnom rozsahu a híbke.

Viera Žemberová sa narodila do historicky a kultúrne podnetného prostredia mesta Levoče, avšak jej cesta za vzdelaním ju zaviedla do hlavných centier regiónu - strednú školu absolvovala v Košiciach a na ňu úspešne nadviazala v rokoch 1967-1972 štúdiom slovenčiny a dejepisu na Filozofickej fakulte Univerzity P. J. Šafárika v Prešove. So svojou alma mater nakoniec spojila svoj profesijný vývoj natrvalo, ked’že tu zostala pôsobit najprv ako asistentka a následne, v pomerne krátkom čase vzhladom k svojim rastúcim odborným znalostiam a úsiliu, postúpila v rámci vedeckého a akademického rebríčka až na pomyselný vrchol - v roku 1976 obhájila titul PhDr., v roku 1984 jej bola udelená vedecká hodnost' kandidát vied (CSc.), v habilitačnom konaní bola nakoniec menovaná docentkou a v roku 1998 i profesorkou. Viera Žemberová pri svojom pôsobení na Univerzite P. J. Šafárika v Prešove (dnes Prešovská univerzita v Prešove) neobmedzila svoje aktivity len na oblast’ vedeckú a pedagogickú, ale prepožičala svoje schopnosti, znalosti a skúsenosti aj k rozvoju Filozofickej fakulty PU v Prešove ako jej prodekanka pre vedu, umeleckú činnost’ a doktorandské štúdium.

Kým osobný a profesijný život Viery Žemberovej je primárne spojený s regiónom východného Slovenska, jej pôsobenie a hlavne jej odborný impakt však túto oblast d’aleko presahujú dosahujúc medzinárodných kvalít - profesorka Žemberová pôsobila ako pedagogička v rámci študijných pobytov i trvalo na univerzitách v Pol’sku, Mad’arsku, Rusku, Českej republike i na Ukrajine, bola a stále je pravidelnou a cenenou účastníčkou zahraničných konferencií, hostujúcou prednášajúcou. Jej vedeckú orientáciu nemožno zhrnút do niekol'kých viet. Dokazujú to i jej vysoko nadpriemerné publikačné aktivity, ako aj účast̉ na odborných konferenciách a kolokviách. Vo všeobecnosti možno tvrdit, že odborný záujem Viery Žemberovej sa sústreduje predovšetkým na literárnovedné bádanie problematiky slovenskej prózy 19. - 21. storočia. Toto vymedzenie odštartovala už dizertačnou prácou s názvom Slovenská historická próza medzivojnového obdobia. Martin Kukučín, Ladislav Nádaši Jégé, Martin Rázus. Nasledovalo obdobie, v ktorom sa venovala problematike literatúry pre deti a mládež; reflektovala poetologické a estetické súvislosti a autorské stratégie v literárnom diele; upriamovala pozornost́ na dejiny literatúry ako na živý organizmus, v ktorom vzájomne komunikujú autor, jeho tvorivá metóda a dielo, ale zároveň zostavila aj výbery z poézie, participovala na tvorbe stredoškolských, ale i vysokoškolských učebníc a príručiek. V desiatych rokoch 21. storočia na prešovskej akademickej 
pôde výrazne prispela k zintenzívneniu záujmu o genologický výskum projektom Genologické a medziliterárne štúdie, z ktorého následne vznikli dva vedecké zborníky, pričom sa žánrovej problematike venovala aj v samostatnej monografii Žáner v pohybe - pohyby žánru vydanej v roku 2012. Charakteristickým znakom vedeckých výstupov Viery Žemberovej najmä $\mathrm{z}$ posledných rokov je tendencia koncipovat ich $\mathrm{v}$ širšom slavistickom kontexte, najmä s presahom do ruského a ukrajinského literárneho priestoru. Neodmyslitelnou súčastou vedeckej pozornosti jubilujúcej profesorky je žena ako autorský subjekt, ktorej sa venuje $\mathrm{v}$ desiatkach svojich odborných prác a pomáha tak zintenzívňovat povedomie o slovenských spisovatelkách minulých, ako i tých súčasných.

$\mathrm{V}$ neposlednom rade, práve tu - v literárnom periodiku Filozofickej fakulty Masarykovej univerzity - je nutné vyzdvihnút i cenný prínos Viery Žemberovej najskôr ako riadnej pracovníčky Ústavu slavistiky FF MU, neskôr ako externej spolupracovníčky. Od roku 2008 rozširovala na brnianskej pôde povedomie o slovenskej literatúre a kultúrnych dejinách, pričom prednášala nielen pre študentov slovakistiky. Len v rámci tohto pracoviska viedla takmer tri desiatky záverečných prác. Od roku 1998 nájdeme iba v digitálnej knižnici Masarykovej univerzity viac ako 100 jej uverejnených štúdií, recenzií, materiálov a marginálií.

Profesorka Viera Žemberová prednáša, píše, vzdeláva, vedie záverečné práce, vd’aka čomu prispieva k pestovaniu slovenskej kultúrnej identity už 46 rokov. Za jej odhodlanie, vytrvalost̉ a vykonanú prácu jej patrí vel'ká vd’aka nás všetkých.

\section{Mgr. Eliška Gunišová}

Ústav slavistiky

Filozofická fakulta, Masarykova univerzita

Arna Nováka 1, 60200 Brno, Česká republika

egunisova@gmail.com 